\title{
CINEMA CONCERT HALL "UKRAINE" IN KHARKIV. FEATURES OF CREATION AND MODERN STATE
}

\author{
${ }^{1}$ Kachemtseva L.V., Candidate of Architecture, Associate Professor, \\ kachemtsevalubov@gmail.com, ORCID: 0000-0003-3564-0537 \\ ${ }^{1}$ Tymchenko D.D., student, \\ d.d.timchenko@gmail.com, ORCID: 0000-0002-3519-2829 \\ ${ }^{1}$ Khakiv National University of Civil Engineering and Architecture \\ 40, Sumska str., M. Khakiv, 61002, Ukraine
}

\begin{abstract}
Today, researchers' interest in the architecture of the USSR during the late 50s and early 70s of the 20th century is growing rapidly, since these years have left behind an outstanding architectural heritage. Many aspects of industrial architecture are being studied, one of which is the phenomenon of the emergence of atypical author's public buildings.

The paper discusses the features of the creation and the current state of the Cinema and Concert Hall "Ukraine" - one of the unique objects of the early 1960s, built in Kharkiv. To achieve the goal, the authors formulated the following research objectives: to consider literary sources that provide general information about the $\mathrm{CCH}$ "Ukraine"; find and analyze authors' articles and publications written by a design team of architects, as well as experts in various fields; to classify and summarize the received material; analyze the current state of the structure.

The article describes the design site in the city garden named after T. G. Shevchenko, on the site of which there was a summer open-air musical stage, in need of restoration due to the impossibility of its use. Presented is a group of architects who developed the project for the new building, and under whose leadership the construction was carried out. The author's concept of the design solution and the stages of its implementation are considered. The main purpose of the project was showing films, holding concerts of symphonic music, performing by pop groups and soloists, as well as organizing rallies and meetings.

The features of space planning (composition, functional zoning) and architectural (interior, external design) solutions of the investigated object are revealed. An innovative, for that time, constructive solution of the structure was analyzed in detail and described - hanging cable-stayed structures of a saddle shape. A brief history of this constructive system is given.

Particular attention is paid to the current state of the CCH "Ukraine", since on August 12, 2021, the facility was opened after a long reconstruction. Presented and described are the project proposals for reconstruction, made by the Ukrainian architectural bureau.
\end{abstract}

Keywords: Cinema and Concert Hall "Ukraine", author's concept, design solution, innovative design solution, hanging cable-stayed covering.

Introduction. Today, researchers' interest in the architecture of the USSR during the late 50s - early 70s of the 20th century is growing, because these years have left behind a great legacy that requires careful study and objective assessment. Many aspects of industrial architecture are investigated, one of which is the phenomenon of the appearance of atypical author's projects of public buildings.

In 1954, the decree "About eliminating excesses in design and civil engineering" was issued, which marked the beginning of a new era in the architecture of the USSR. The Khrushchev architectural revolution, which some researchers refer to as a revenge to constructivism, made "technologism" the main reference point for architects. The main task of architects and builders was to solve the problem of the shortage of housing in the country as quickly as possible. At this time, in parallel with the construction of standard multi-story residential buildings, innovative design ideas 
appeared. The Cinema and Concert Hall "Ukraine" in Kharkiv is one of the unique buildings of the early 1960s, an integral part of the architectural heritage of Kharkiv and Ukraine as a whole. For a long time, this building was one of the architectural visiting cards of the city, its photos were necessarily included in the presentation albums of Kharkiv, and since 1980 the building was taken under state protection as a monument of architecture and urban planning of local importance. Therefore, it is surprising that over the years, the understanding of the value of this building and its place in the history of architecture began to fade away.

Analysis of recent research and publications. In recent years, there are few professional publications related to the research topic. Among them is the work of Yu.M. Yarovyi, Ye.A. Perepelytsia, D.V. Chibarov "Investigation of the hanging cover of the CCH "Ukraine" in Kharkiv" [1], which describes in detail the structural system of the building and analyzes its state in 2015. In the article by G.V. Semiakyn "Kharkiv circus on the embankment. Continuity of the typology of circus buildings" [2] the building of the Cinema and Concert Hall "Ukraine" is also mentioned as a landmark object, in the construction of which innovative structures for that time were used. Recently, there have been several online publications related to the process of building renovation [3]. Therefore, the main sources of information are materials of the last century.

The Cinema and Concert Hall "Ukraine" began to attract attention even before the construction of the building was completed. In the December issue of the magazine "Budivnytstvo ta Arkhitektura" 1962 was published an article "Construction of a musical stage in Kharkiv" [4], which gives a brief description of the space-planning and structural design of the building. Subsequent publications appeared only after the completion of the Cinema and Concert Hall. On September 28, 1963 in the newspaper "Komsomolskyi Stiah" in the essay "Palace of the Muses" [5], the original interior of the Cinema and Concert Hall "Ukraine" was described. Interesting details of the internal professional equipment are given in the article "Cinema and Concert Hall "Ukraine" [6], which was published in the August 1964 in magazine "Kinomekhanik". In addition, this year, two articles were published on the architectural and constructive solution of the structure: "Features of the new in the architecture of public buildings" [7], and "Hall "Ukraine" in Kharkiv" [8]. The author's group of the project wrote the last article in July 1964 in the journal "Arkhitektura SRSR".

Some information about the general information about the Cinema and Concert Hall "Ukraine" can be obtained from the presentation albums of Kharkiv and Ukraine, such as: "Modern architecture of Soviet Ukraine" [9], "Kharkiv: Architecture, memorials. Photo Album" [10], "Architecture of Soviet Ukraine" [11].

In 1972, the design materials for the CCH "Ukraine" were deposited in the Central State Archive of Scientific and Technical Documentation (CSASTD) of the Ukrainian SSR from the State Design and Research Institute "Kharkiv PrombudNDIproekt" of the State Construction Committee of the Ukrainian SSR [12]. Now the following documents are stored in CSASTD:

- project of reconstruction of the summer music stage in the Shevchenko City Garden in Kharkiv. Explanatory note and drawings [13];

- reconstruction of the summer music stage in the Shevchenko City Garden in Kharkiv for the summer Cinema and Concert Hall. Explanatory note and final drawings [14];

- summary estimate of the reconstruction of the musical stage for the Cinema and Concert Hall in the Shevchenko Garden [15].

The Cinema and Concert Hall "Ukraine" was an innovative project, its structures were used for the first time on the territory of the Ukrainian SSR. In the book "Fundamentals of Architectural Composition and Design" [16] (edited by A. A. Tic) in the history of the development of cablestayed structures, a separate place is given to the $\mathrm{CCH}$ "Ukraine". A description of the structural system of this structure can be found in the professional technical literature from the calculation of cable-stayed structures $[17,18] 60 \mathrm{~s}-70$ s of the 20th century.

Problem statement. In the national professional literature, the Cinema and Concert Hall "Ukraine" has been mentioned extremely rarely in recent years, and is clearly underestimated. This building occupies a special place in the history of national architecture of the 20th century, requires

Bulletin of Odessa State Academy of Civil Engineering and Architecture, 2021, no. 85, page 9-17 
study and professional assessment. In recent years, $\mathrm{CCH}$ "Ukraine" was in a state of reconstruction, which drew attention to this object and made its research necessary.

Aim and tasks of research. The purpose of the work is to investigate the features of creating the Cinema and Concert Hall "Ukraine" in Kharkiv from the idea of the project to its implementation and to analyze the current state of the building.

To achieve this goal, the following tasks were set:

- to consider the circumstances that led to the creation of $\mathrm{CCH}$ "Ukraine";

- to identify the features of the volumetric-spatial and functional solutions of the Cinema and Concert Hall;

- to determine the features of the constructive solution of the object;

- to fix the current state of the structure.

Methods of research. Research is based on the identification and compilation of factual material. In the course of the work, historical-theoretical and local history publications, periodicals, archival, design and illustrative materials were analyzed and systematized. The article analyzes the articles of the authors of the project $\mathrm{CCH}$ "Ukraine" on the implementation and commissioning of the Cinema and Concert Hall "Ukraine".

Presentation of the main material. At the end of the 50s of the 20th century, the population of Kharkiv grew rapidly, because the city continued to develop as an industrial, scientific, educational and cultural center. The main task of architects in these years was the development and construction of areas of mass housing, located in the residential areas of the city. Rapid construction and population growth have led to the need to improve the global infrastructure of the city: solving the problem of transport, launching the subway, landscaping and improving the city.

One of the favorite recreation places of Kharkiv citizens was the Shevchenko City Garden, which was revived and reincarnated in architectural, planning and aesthetic relations. A cascade stairs were built here from the side of the Klochkivski slopes, and it became necessary to reconstruct an open musical stage [19].

The open musical stage in the Shevchenko City Garden was built in 1946-1947. The open theater was located in the area of the park farthest from external noise sources, at the point where it adjoins the vast territory of the zoo, and was connected to the central alley by narrow pedestrian paths. The theater accommodated 1800 spectators; its architectural appearance was distinguished by its simplicity and restraint [20].

The project, ordered by the Kharkiv City Department of Public Utilities, provided for a complete reconstruction of the stage shell and fencing, due to the impossibility of using them. In addition, the document for reconstruction indicated that all other structures on the site, as well as green spaces, must be preserved [13].

In December 1958 - January 1959, a competition was held for the best project of covering a musical stage in the Shevchenko City Garden in the Kharkiv. According to the jury's decision, the final project was based on a joint author's development, carried out by Kharkiv architects V. S. Vasyliev (Kharkiv branch of Dipromist), Yu. O. Plaksiiev and engineer L. B. Fridhan (Kharkiv branch of Prombudproekt). In the archival documents, it is noted that engineers also took part in the development of the design problem: N. O. Shvets - the plumbing part, L. N. Serednytskyi - electric lighting, M. G. Tsirlin - estimate and financial calculations. In reference books, as well as on a memorial plaque fixed on the building of the $\mathrm{CCH}$ "Ukraine", this list is wider. In particular, the honored builder of the Ukrainian SSR, honorary citizen of Kharkiv V. O. Reusov is named among the authors [12].

The project stipulated that "all existing alleys, except for the one running along the fence of the zoo, will be preserved. In addition, arrays of green spaces along them are stored. The checkout booths are separated from the music stage building, which allows relieving the main avenues and providing a convenient evacuation. Bathrooms for spectators are assigned to the western part of the foyer and are located behind a fence.

The existing buffet building is being reconstructed and, according to the project, should serve both garden visitors and spectators. The stage in front of the stage does not change its configuration.

Bulletin of Odessa State Academy of Civil Engineering and Architecture, 2021, no. 85, page 9-17 
A cafe building should bound it from the north and a lattice of pergolas shrouded in greenery, from the west by the entrances to the Cinema and Concert Hall and three flagpoles, and from the other sides by arrays of greenery. A small round reservoir with a fountain was designed in the center of the site" [14, c. 15].

As conceived by the designers, the main volume of the building was supposed to be located within the existing musical stage; the capacity of the Hall remained within the existing one for 1800-2000 people. The Hall was supposed to be universal. It is designed for demonstration of largeformat and ordinary films, concerts of pop and symphonic music, as well as rallies and meetings. As a result of a preliminary study of a number of variants, the authors settled on the compositional solution of the Hall in the form of a single amphitheater, covered with a suspended reinforced concrete vault-shell of double curvature. The constructive scheme and space-planning structure were chosen taking into account the complex solution of acoustics requirements, ensuring good visibility conditions and quick evacuation of spectators $[4,7,8]$.

Two stages of construction were envisaged. The first stage provided seasonal use of the premises; after the second stage, the operation of the Cinema and Concert Hall was supposed to become possible throughout the year. However, even at the first stage of construction, a coating was created that meets the requirements of the year-round operation of the building [8].

The main part of the building dominates in the overall composition of the object - an auditorium with small lobbies and an open stage. About $60 \%$ of the seats were located in the stalls, the rest in the amphitheater, which ensures good visibility for all spectators. When arranging couloirs, the space under the amphitheater was used rationally. To ensure the free flow of spectators into the building and their quick evacuation, there are two entrances from the side of the main facade, and in the side parts of the building - six exits to the garden, where there are unloading platforms associated with park alleys $[4,7]$.

The second stage of construction involved joining a one-story extension to the main volume. It was supposed to accommodate a cashier's lobby, a wardrobe, a lobby and other utility rooms. It is expected that during the cold months the hall will be loaded through the foyer on one side. But the second stage of construction was not implemented [8].

The construction of the facility was conceived as an experimental one, with the introduction of new progressive structures and materials. Thanks to the successful implementation of the project, $\mathrm{CCH}$ "Ukraine" became one of the first structures in the country with cable-stayed saddle-shaped coatings $[17,18]$.

The first metal suspended coverings appeared at the end of the 19th century, the Russian engineer V. R. Shukhov as early as 1895 , received a patent for hanging cable-stayed coverings. The advantages of these progressive structures were demonstrated to them the following year in the pavilion of the All-Russian Exhibition in Nizhny Novgorod. However, it took half a century for cable-stayed structures to become actively used in architecture. A big step in the development of hanging structures was the construction of the roof of the indoor arena of the stadium in 1953 in the city of Rally, North Carolina, USA [16, 21].

In the USSR, the use of hanging structures began in 1958-1960 with the construction of a summer cinema in Baku, the structures of which, unfortunately, have not survived (they were destroyed in 2005 during a major overhaul of the theater). A children's theater was also built in Baku with a paraboloid-shaped coating measuring $20 \times 30 \mathrm{~m}$ according to the Bakhipromist project. In 1960, in Tallinn, according to the drawings of Estonproekt, a hanging canopy was erected with a span of $75 \mathrm{~m}$ above the stage of the Song Festival Grounds. In 1960, the project CCH "Ukraine" in Kharkiv was completed, and in 1963, this facility was put into operation [8, 22, 23].

The constructive solution of the Cinema and Concert Hall in Kharkiv is new and original. The overlap over the hall is made in the form of a thin-walled reinforced-cement shell of double curvature, suspended from a system of load bearing and tension cables. The shell parameters are close to a hyperbolic paraboloid with the largest dimensions 45 and $48 \mathrm{~m}$ in horizontal projection. The shell loads are received by two reinforced concrete parabolic arches and transferred to the monolithic support foundations. The desire to rationally use the volume of the hall, which is 
covered by the shell, and to provide the best acoustics in it, has led to the creation of an asymmetric suspension system, in which the contour arches have different sizes and slopes to the horizon $-12^{\circ}$ and $45^{\circ}[4,7,8]$.

Along the perimeter of the hall, light reinforced concrete racks (with a cross-section of $45 \times 20 \mathrm{~cm}$ ) are installed, which act as rigid braces that fix the arches, as well as a load-bearing fence and are part of the structure of the stands from the side of the main facade. During the erection of the bearing contour, these props were used to manufacture the suspended formwork of the arches [8].

As load-bearing elements of the coating, bundles of steel wire were used, equipped at the ends with sleeve anchors, which were reinforced in metal rods removed from the concrete. The tensioning cross-member system consists of flexible steel ropes, with the help of which the pretension was carried out during the installation of the cover. The longitudinal suspension cables sag due to their own weight. When tensioning the transverse ropes, they also get curvature in the vertical plane. This creates significant difficulties in typing coverage items. Theoretically, each cell, formed by two supporting and two tightening cables, has its own, unique to it, dimensions and angles. The task of ensuring the prefabrication of the elements was solved by creating a special design of reinforced cement slabs with joints that are monolithic to each other. This made it possible to cover the hall with slabs of the same standard size $(200 \times 100 \times 3 \mathrm{~cm})[4,7,8]$.

The architectural solution of the interior is based on the contrast of tones: the white body of the shell, the calm dark brown tone of the armchairs and the colored stained-glass windows of the fence along the perimeter of the building. Wood, fiberglass, plastics are widely used in processing [7].

We can also learn about the original interior from the article by I. Burau "New Cinema and Concert Hall "Ukraine"", published in 1963 in the newspaper "Komsomolskyi Stiah" immediately after the object was put into operation:

"The auditorium is spread out like a huge amphitheater. Everything is thought out here, everything is done <...> smartly and gracefully. Wall cladding made of colored glass does not transmit ultraviolet rays. Thanks to this, it is cool in the hall, and films can be shown during the day without worrying about darkening.

The corrugated pine trim is in perfect harmony with the comfortable brown armchairs. They were specially made for the new hall by the Kharkiv Plastic Plant. <...> we look into the cinema through the viewing window. The image on the screen is clear; focusing is excellent. By the way, a special remote control is installed in the hall, which allows you to adjust the brightness of the image and sound at any moment. "Ukraine" has excellent acoustics, although there are no absorbers or any special devices at all. The very shape of the hall achieves great sound. I must say that the new structure has already been tested "comprehensively"" [6, c. 5].

The external arrangement was also made in the spirit of the times. In the composition of the main facade, the horizontal architrave above the main entrance is opposed to the frequent rhythm of the vertical imposts of the stained-glass window. A neon sign on an aluminum-corrugated belt emphasizes the horizontal position of the architrave under night lighting. Thus, architectural and structural details, lighting and advertising elements, fulfilling their role, form a single compositional whole [8].

A characteristic feature of the building is a clear functional organization and the unity of the architectural form of the entire structure and its structure. There is nothing far-fetched and unnecessary. The use by the authors of the possibilities of new structures, finishing materials, elements of decorative and applied art meets the general realistic orientation of the architecture of that period. The lightweight stained-glass wall railing made of colored glass with aluminum overlays gives the architecture of the main façade a special aesthetic expressiveness. A thematic panel of black, yellow, white and blue ceramic tiles, made on the portal of the main façade, contrasts well with large glazed surfaces [7].

In 2015, a comprehensive survey of the bearing and enclosing structures of the covering of the Cinema and Concert Hall building was carried out, the results of which were published [1].

Bulletin of Odessa State Academy of Civil Engineering and Architecture, 2021, no. 85, page 9-17 
During the survey, the drawings of the project 40501-01 "Cinema and Concert Hall in the Shevchenko Garden in Kharkiv" [12-15], developed by Kharkiv Prombudproekt, as well as the results of preliminary examinations $[25,26]$.

"Based on the work performed, including the collection and analysis of technical documentation, field surveys, instrumental studies, control measurements of sections of structures, analysis of defects and damage to the bearing and enclosing structures of the building of the Cinema and Concert Hall "Ukraine", revealed during the survey, bearing and stressing cables, coating slabs are in a satisfactory condition (category II), the roof of the building is in a condition unsuitable for further operation (category III)" [1, p. 99]: The results of the survey, recommendations for ensuring further normal operation are presented in the conclusions of the technical condition [25].

In 2017, the VizDom Space architectural bureau took part in the development of a draft proposal for the reconstruction of the Cinema and Concert Hall "Ukraine". The architects presented two options for transforming the building for the maximum and minimum budget. The first involves the construction of an underground floor with sanitary facilities and a wardrobe. The second floor of the administrative part is also being built. In place of the old boiler room and the street toilet, twostorey buildings are being built, connected by passages. The premises in these buildings are used for renting out and organizing various activities for young people. The second version of the project proposal does not imply a grandiose approach; it is aimed only at adding the functions necessary for the comfortable functioning of the hall without introducing additional possibilities for using the spaces. Only the most necessary premises are being completed. It is also planned to build an underground floor with sanitary facilities, a cloakroom and a second floor superstructure in the administrative part, as in the first version [3].

The Kharkiv City Council allocated 55 million hryvnias for the reconstruction of the Cinema and Concert Hall, which lasted during 2019-2021. During this time, the facade was completely renovated, the windows were replaced, the panels at the entrance were restored, even the letters in the style of the sixties. All communications were replaced inside. We arranged places for internal sanitary facilities, carried out work on arranging dressing rooms for artists with showers, tiled walls and equipped the Hall. "Ukraine" was updated to preserve its original appearance to the smallest detail, primarily the exterior of the building.

Conclusions and prospects for further research. The Cinema and Concert Hall "Ukraine" in Kharkiv is one of the first objects in the USSR, in which new and progressive structures were used - hanging cable-stayed structures, and in Ukraine, this structure was the first author's project using these innovative constructive solutions for that time. Later, cable-stayed structures developed and had large-scale implementation in other objects. However, $\mathrm{CCH}$ "Ukraine" will forever remain the first for our country.

The winners of the competition (December 1958 - January 1959) for the best project of covering the musical stage in the Shevchenko Garden in Kharkiv formed the basis of the group of authors for the project of the CCH "Ukraine" (completed in 1960). This facility was built in 1963.

Speaking about the peculiarities of the creation of the $\mathrm{CCH}$ "Ukraine" in Kharkiv, it should be noted that the design and construction of the facility took place as an experimental one with the introduction of new structures and materials.

A clear functional organization, the unity of the architectural form of the entire structure and its design, the use by the authors of the possibilities of new finishing materials, elements of decorative and applied art made the $\mathrm{CCH}$ "Ukraine" one of the best examples of a public building of its time in the country.

Now, the reconstruction of the Cinema and Concert Hall "Ukraine" has been completed; on August 12, 2021, it was opened to visitors. The restoration work was carried out quite competently and correctly, with the preservation of the architectural and structural features of this building, which made it possible to preserve its status as an architectural monument of local importance.

Based on the results of the restoration work performed, a number of professional publications should appear, expanding our knowledge of this unique architectural structure. 
The study of the history of the $\mathrm{CCH}$ "Ukraine" and the disclosure of the features of the creation of the structure is a desire to pay tribute to the authors of the project: Vadym Serhiiovych Vasyliev, Yurii Oleksiiovych Plaksiiev, Volodymyr Oleksiiovych Reusov, who for many years taught at the Kharkiv Civil Engineering Institute (KhSTUCEA, KhNUCEA to create the Kharkiv architectural schools).

\section{References}

[1] Yu.M. Yarovyi, Ye.A. Perepelytsia, D.V. Chibarov, "Doslidzhennia vysiachoho pokryttia KKZ "Ukraina" v m Kharkovi", Naukovyi visnyk budivnytstva, vol. 1 (83), pp. 95-100, 2016.

[2] H.V. Semiakyn, "Kharkovskyi tsyrk na naberezhnoi. Preemstvennost typolohyy tsyrkovыkh zdanyi", Suchasni problemy arkhitektury ta mistobuduvannia: Nauk.-tekhn. zbirnyk, vol. 1 35, pp. 90-101, 2014.

[3] Jeskiznoe predlozhenie po rekonstrukcii KKZ «Ukraina» v gorode Har'kove [Online]. Available: https://www.vizdome.space/projects/jeskiznoe-predlozhenie-po-rekonstrukciikkz-ukraina-v-gorode-harkove/

[4] V. Moiseenko, "Zdanie muzykal'noj jestrady v Har'kove", Stroitel'stvo i arhitektura, vol. 12, pp. 23-24, 1962.

[5] I. Burau, "Dvorec muz", Komsomol'skoe znamja, p. 13, 1963.

[6] D. Voloshin, "Kinokoncertnyj zal 'Ukraina'", Kinomehanik, vol. 8, pp. 18-19, 1964.

[7] E. Svjatchenko, "Cherty novogo v arhitekture obshhestvennyh zdanij", Stroitel'stvo $i$ arhitektura, vol. 3, pp. 12-13, 1964.

[8] V. Vasil'ev, Ju. Plaksiev, V. Reusov, L. Fridgan, "Kinokoncertnyj zal 'Ukraina'”, Arhitektura SSSR, vol. 17, pp. 42-45, 1964.

[9] H.V. Holovko, S.K. Kilesso, M.S. Kolomiiets, Yu.F. Khokhol, Suchasna arkhitektura radianskoi Ukrainy. Kyiv: Budivelnyk, 1974.

[10] A.O. Horshkov, V.T. Semenov, O.O. Tits, Kharkiv: Arkhitektura, pamiatky. Fotoalbom. Kyiv: Mystetstvo, 1986.

[11] I.N. Sedak, V.P. Dahno, Ju.I. Piskovskij, V.E. Ladnyj, Arhitektura Sovetskoj Ukrainy. Moskva: Strojizdat, 1987.

[12] TsDNTAU, Kinokoncertnyj zal v g.Har'kove v sadu im. T.G. Shevchenko. Kharkiv, 1972.

[13] TsDNTAU, Proekt rekonstrukcii letnej muzykal'noj jestrady v gorodskom sadu im. T. G. Shevchenko v Har'kove. Pojasnitel'naja zapiska i chertezhi. Kharkiv, 1959.

[14] TsDNTAU, Rekonstrukcija letnej muzykal'noj jestrady v gorodskom sadu im. T. G. Shevchenko $v$ g. Har'kove pod letnij kinokoncertnyj zal. Pojasnitel'naja zapiska $i$ chertezhi okonchatel'nye. Kharkiv, 1959.

[15] TsDNTAU, Svodnaja smeta rekonstrukcii muzjestrady pod kinokoncertnyj zal $v$ sadu Shevchenko. Kharkiv, 1960.

[16] A.A. Tic, Ju.G. Bozhko, G.I. Ivanova, Osnovy arhitekturnoj kompozicii $i$ proektirovanija. Izdatel'skoe objedinenie 'Vysshaja shkola', 1976.

[17] V.S. Vasil'ev, Ju.A. Plaksiev, V.A. Reusov, L.B. Fridgan, Visjachee sedloobraznoe pokrytie. Kyiv: Budivelnyk, 1965.

[18] L.G. Dmitriev, Vantovye pokrytija. Raschet i konstruirovanie. Kyiv: Budivelnyk, 1974.

[19] Ju.M. Shkodovskij, I.N. Lavrent'ev, A.Ju. Lejbfrejd, Ju.Ju. Poljakova, Har'kov vchera, segodnja, zavtra. Har'kov: Folio, 2002.

[21] V.E. Bykov, Arhitektura otkrytyh teatrov. Moskva: Gos. izd-vo lit. po stroitel'stvu i arhitekture, 1954.

[21] Survey and Planning Unit Staff (August 1972). "J.S. Dorton Arena”, National Register of Historic Places. North Carolina State Historic Preservation Office, 2015.

[22] A.M. Anishhenko, Arhitektura sooruzhenij s visjachimi pokrytijami. Kyiv: Budivelnyk, 1970. 
[23] Visjachie pokrytija: trudy soveshhanija po issledovaniju i vnedreniju visjachih pokrytij. Nauchno-issledovatel'skij institut betona i zhelezobetona. Moskva: Gosudarstvennoe izdatel'stvo literatury po stroitel'stvu, arhitekture i stroitel'nym materialam, 1962.

[24] Tehnicheskij otchet ob inzhenerno-geode-zicheskih rabotah po opredeleniju peremeshhenij osnovnyh fundamentov kino-koncertnogo zala «Ukraina» $v$ g. Har'kove. Har'kov: Vostochno-Ukrainskij Gosudarstvennyj institut inzhenerno-tehnicheskih izyskanij «UKRVOSTOK-GIINTIZ», 1987.

[25] Otchet "Vypolnenie rabot po vyboroch-nomu predvaritel'nomu obsledovaniju nesushhih $i$ ograzhdajushhih konstrukcij kinokoncertnogo zala 'Ukraina' v g. Har'kove, razrabotka chertezhej proekta proizvodstva rabot, a tak zhe soputstvujushhie stroitel'nye raboty na vypolnenie jetih rabot". Har'kov: KP Proektnyj i nauchno-issledovatel'skij institut «Har'kovskij Promstrojniiproekt», 1998.

[26] Zakljuchenie o tehnicheskom sostojanii nesushhih konstrukcij zala dlja zritelej zdanija kinokoncertnogo zala «Ukraina», raspolozhennogo po adresu: g. Har'kov, ul. Sumskaja, 35. Razrabotka tehnicheskih reshenij i rekomendacij po obespecheniju dal'nejshej normal'noj jekspluatacii. Har'kov: HNUSA, 2015.

\title{
КІНОКОНЦЕРТНА ЗАЛА «УКРАЇНА» В ХАРКОВІ. ОСОБЛИВОСТІ СТВОРЕННЯ ТА СУЧАСНИЙ СТАН
}

\author{
${ }^{1}$ Качемцева Л.В., к.арх., доцент, \\ kachemtsevalubov@gmail.com, ORCID: 0000-0003-3564-0537 \\ ${ }^{1}$ Тимченко Д.Д., студент, \\ d.d.timchenko@gmail.com, ORCID:0000-0002-3519-2829 \\ ${ }^{1}$ Харківський національний університет будівництва та архітектури \\ вул. Сумська, 40, м. Харків, 61002, Україна
}

Анотація. Сьогодні інтерес дослідників до архітектури СРСР періоду кінця 50-х початку 70-х років XX століття стрімко зростає, тому що ці роки залишили після себе видатну архітектурну спадщину. Вивчається безліч аспектів індустріальної архітектури, одним із яких є феномен виникнення нетипових авторських суспільних споруд.

У роботі розглянуто особливості створення та сучасний стан кіноконцертної зали «Україна» - одного з унікальних об'єктів початку 1960-х років, збудованих у Харкові. Для досягнення мети авторами було сформульовано такі завдання дослідження: розглянути літературні джерела, що надають загальну інформацію про ККЗ «Україна»; знайти та проаналізувати авторські статті та публікації, написані проектною групою архітекторів, а також експертами різних областей; класифікувати та узагальнити отриманий матеріал; проаналізувати сучасний стан споруди.

У статті описано ділянку проектування у міському саду ім. Т. Г. Шевченка, на місці якої було розташовано літню відкриту музичну естраду, яка потребувала реставрації у зв’язку з неможливістю їі використання. Представлено групу архітекторів, яка розробляла проект нової споруди, та під керівництвом якої велося будівництво. Розглянуто авторську концепцію проектного рішення та етапи його реалізації. Основним призначенням проекту були: показ фільмів, проведення концертів симфонічної музики, виступ естрадних колективів та солістів, а також організація мітингів та масових зібрань.

Виявлено особливості об'ємно-планувального (композиція, функціональне зонування) та архітектурного (інтер'єр, зовнішнє оформлення) рішень об'єкта, який досліджується. Детально проаналізовано та описано новаторське, для того часу, конструктивне рішення споруди - висячі вантові конструкції сідлоподібної форми. Наведено коротку історію цієї конструктивної системи. 
Особлива увага у роботі приділена сучасному стану ККЗ «Україна», оскільки 12 серпня 2021 року об'єкт було відкрито після тривалої реконструкції. Подано та описано проектні пропозиції реконструкції, виконані українським архітектурним бюро.

Ключові слова: кіноконцертна зала «Україна», авторська концепція, проектне рішення, новаторське конструктивне рішення, висячі вантові покриття.

\title{
КИНОКОНЦЕРТНЫЙ ЗАЛ «УКРАИНА» В ХАРЬКОВЕ. ОСОБЕННОСТИ СОЗДАНИЯ И СОВРЕМЕННОЕ СОСТОЯНИЕ
}

\author{
${ }^{1}$ Качемцева Л.В., к.арх., доцент, \\ kachemtsevalubov@gmail.com, ORCID: 0000-0003-3564-0537 \\ ${ }^{1}$ Тимченко Д.Д., студент, \\ d.d.timchenko@gmail.com, ORCID: 0000-0002-3519-2829 \\ ${ }^{1}$ Харьковский национальный университет строительства и архитектуры \\ ул. Сумская, 40, м. Харьков, 61002, Украина
}

\begin{abstract}
Аннотация. Сегодня интерес исследователей к архитектуре СССР периода конца 50-х начала 70-х годов XX века стремительно возрастает, так как эти годы оставили после себя выдающиеся архитектурное наследие. Изучается множество аспектов индустриальной архитектуры, одним из которых является феномен возникновения нетиповых авторских общественных сооружений.

В работе рассмотрено особенности создания и современное состояние киноконцертного зала «Украина» - одного из уникальных объектов начала 1960-х годов, построенных в Харькове. Для достижения цели авторами были сформулированы следующие задачи исследования: рассмотреть литературные источники, которые дают общую информацию о ККЗ «Украина»; найти и проанализировать авторские статьи и публикации, написанные проектной группой архитекторов, а также экспертами различных областей; классифицировать и обобщить полученный материал; проанализировать современное состояние сооружения.

В статье описано участок проектирования в городском саду им. Т. Г. Шевченка, на месте которого располагалась летняя открытая музыкальная эстрада, нуждающаяся в реставрации в связи с невозможностью ее использования. Представлено группу архитекторов, которая разрабатывала проект нового сооружения, и, под руководством которой велось строительство. Рассмотрено авторскую концепцию проектного решения и этапы его реализации. Основным предназначением проекта были: показ фильмов, проведение концертов симфонической музыки, выступление эстрадных коллективов и солистов, а также организация митингов и собраний.

Выявлено особенности объемно-планировочного (композиция, функциональное зонирование) и архитектурного (интерьер, внешнее оформление) решений исследуемого объекта. Детально проанализировано и описано новаторское, для того времени, конструктивное решение сооружения - висячие вантовые конструкции седлообразной формы. Приведено краткую историю данной конструктивной системы.

Oсобое внимание в работе уделено современному состоянию ККЗ «Украина», так как 12 августа 2021 года объект был открыт после длительной реконструкции. Представлено и описано проектные предложения реконструкции, выполненные украинским архитектурным бюро.

Ключевые слова: киноконцертный зал «Украина», авторская концепция, проектное решение, новаторское конструктивное решение, висячее вантовое покрытие.
\end{abstract}

Стаття надійшла до редакції 4.11.2021

Bulletin of Odessa State Academy of Civil Engineering and Architecture, 2021, no. 85, page 9-17 